\title{
Organic Agriculture and Innovative Crops under Mediterranean Conditions
}

\section{Dimitrios BILALIS ${ }^{1 *}$, Ioannis ROUSSIS ${ }^{1}$, Francisco FUENTES ${ }^{2}$, Ioanna KAKABOUKI ${ }^{1}$, Ilias TRAVLOS ${ }^{1}$}

\author{
${ }^{1}$ Agricultural University of Athens, School of Agriculture, Engineering and Environmental Sciences, Department of Crop Science, \\ Laboratory of Agronomy, 75 Iera Odos str., 11855 Athens, Greece; bilalisdimitrios@gmail.com (*corresponding author); \\ iroussis01@gmail.com;.kakabouki@gmail.com; htravlos@yahoo.gr \\ ${ }^{2}$ Pontificia Universidad Católica de Chile, Facultad de Agronomía e Ingeniería Forestal, Pontificia Universidad Católica de Chile, \\ Vicuña Mackenna 4860, Macul, Santiago, Chile; frfuentesc@uc.cl
}

\begin{abstract}
Climate change is the greatest environmental threat facing humanity worldwide. Areas of South-East Europe and Mediterranean basin are expected to be among the most vulnerable countries to climate change. As a result of climate change, new species and crops have been introduced and may be introduced in the coming years. In addition, $F A O$ considers that Organic Agriculture is an effective mitigation strategy to climate change and can build robust soils that adapt better to weather extremes associated with climate change. This review provides an overview of the growth performance of new innovative crops, including chia, camelina, quinoa, teff and nigella and retrovative crops such as flax and emmer wheat, based on experimental investigations conducted under Mediterranean conditions and organic cropping system. Several studies, performed under organic system, have proved that innovative crops can also be grown for alternative uses. Quinoa and chia could be successfully used in animal feed. Moreover, quinoa could be exploited as a medicinal plant due to saponins extracted from seed coats. Nigella and camelina seeds contain oils which can have several uses in pharmaceutical and food industries. Flax seed oil is rich in omega- 3 fatty acids and can be accepted in the diets designed for specific health benefits. According to the literature, it is observed that innovative crops cultivated under organic system present better quality and similar yields as with those cultivated under conventional system, and in some cases, even higher. Taking all these into account, organic agriculture could also be characterized as innovative and not only as traditional.
\end{abstract}

Keywords: climate change, innovative crops, Mediterranean conditions, Organic Agriculture, retrovative crops

\section{Introduction}

Climate change consists the greatest environmental threat facing humanity worldwide. It is a natural process but, in the light of recent surveys, this dramatic change is mainly due to the increase of various greenhouse gases (GHG) emissions as a result of anthropogenic reasons. Agriculture is actually affected by climate change but also plays a part in the rise of problem. Agriculture is the third largest contributor of greenhouse gas emissions, mainly including methane $\left(\mathrm{CH}_{4}\right)$, nitrous oxide $\left(\mathrm{N}_{2} \mathrm{O}\right)$ and carbon dioxide $\left(\mathrm{CO}_{2}\right)$. The Intergovernmental Panel on Climate Change (IPCC) states that greenhouse gas (GHG) emissions from the agricultural sector suggest $10-12 \%$ of the total anthropogenic annual emissions of $\mathrm{CO}_{2}$-equivalents
(IPCC, 2007). In addition, agriculture contributes about half of global emissions of methane and nitrous oxide (World Bank, 2008). It has to be noted that emissions due to the production of agricultural inputs such as synthetic fertilizers and pesticides, fossil fuels used in the production of agrochemicals and agricultural machinery and irrigation are not included and should also be taken into account (ElHage Scialabba and Müller-Lindenlauf, 2010). Regarding the high contribution of agriculture to greenhouse gas emissions, the choice of alternative agricultural practices is the only solution to cope with problem of climate change.

Agriculture is highly depended on climate conditions. Changing environmental conditions such as rising temperatures, changes in precipitation patterns and an increase of extreme weather phenomena have the potential to affect productivity in agriculture, making it even more prone to failure (El-Hage and Müller-Lindenlauf, 2010). 
324

The Mediterranean region is characterized by an extremely variable climate with warm dry summers and cool rainy winters (winter rainfall is more than three times summer rainfall), being a transition between dry tropical and temperate climates (Ceccarelli et al., 2007). Mean annual temperatures range from 9 to $20^{\circ} \mathrm{C}$ and mean annual rainfalls vary from 200 to $2000 \mathrm{~mm}$, depending on altitude (Carrubba and Scalenghe, 2012). The future climate change scenarios prognosticate drier and warmer conditions in the Mediterranean region, including southern Europe, as a result of global warming (IPCC, 2007). A mean temperature rise is predicted with values ranging from $2-4{ }^{\circ} \mathrm{C}$ (Georgakopoulos et al., 2016). Moreover, specific forecasting models show that rainfall during the winter will be increased in central and eastern Spain and the northern part of Italy, while in southern Mediterranean countries the rainfall will be decreased by 10-15\% until the year 2050 (Ragab and Prudhomme, 2002).

The influence of climate change is expected to lead to large reductions in Mediterranean crop productivity (Maracchi et al., 2005) with increased water demand hastened maturation and reduced yields for spring crops and geographically variable effects for autumn crops (Rötter and van de Geijn, 1999; Giannakopoulos et al., 2011). Areas of South-East Europe and Mediterranean basin are expected to be among the most vulnerable countries to climate change. As a result of climate change, new species and crops have been introduced and may be introduced in the coming years (Georgakopoulos et al., 2016).

Organic Agriculture is not only able to adapt to the effects of climate change in agriculture-influenced ecosystems but also has the potential to reduce emissions of agricultural greenhouse gases (GHG) (Khanal, 2009). Mitigation is an effort to reduce greenhouse gases that are responsible for climatic change and global warming. The Food and Agriculture Organization of the United Nations (FAO) considers that Organic Agriculture is an effective mitigation strategy to climate change and can build robust soils that adapt better to weather extremes associated with climate change (Niggli et al., 2009). Organic Agriculture as a mitigation strategy addresses both reduction of greenhouse gas emissions and soil carbon sequestration. Reduction of greenhouse gas emissions is achieved through lower $\mathrm{N}_{2} \mathrm{O}$ emissions with lower nitrogen input and less $\mathrm{CO}_{2}$ emissions better soil structure, more plant cover and lower farming system inputs (Müller, 2009). Soil carbon sequestration is increased through agricultural management practices such as the application of organic manures and the use of intercrops and green manures that enhance soil organic matter contents and improve soil structure (Niggli et al., 2007). Therefore, Organic Agriculture helps to increase resilience of farming systems by using recycling techniques and low external input and high output strategies (Kotschi and Müller-Sämann, 2004; Niggli et al., 2007).

This research article attempts to provide an overview of the growth performance of new innovative crops, including chia, camelina, quinoa, teff and nigella and retrovative (from the words retro and innovation) crops such as flax and emmer wheat, based on the first results of experimental studies conducted under Mediterranean conditions and organic cropping system.

\section{Innovative Crops: General Information and First Results of their Cultivation}

Quinoa

Quinoa (Chenopodium quinoa Willd.) has a significant potential for increased production as a new cultivated crop in the Mediterranean region and in other areas of the world including North America, Europe and Asia (Jacobsen, 2003). It is characterized as one of the crops that could provide food security, especially in the future climate scenario of increasing salinization and aridity (Jacobsen, 2003; Ruiz et al., 2014). Quinoa, a member of Chenopodiaceae family, is a pseudocereal crop well adapted to grow under unfavourable soil and climatic conditions (Garcia et al., 2003) and has been traditionally cultivated for thousands of years in the Andean highlands of Bolivia, Peru, and Ecuador for its nutritious grains and leaves (Pearsall, 1992). Archaeological findings in northern Chile have shown that quinoa is cultivated there for more than 7000 years (Jancurová et al., 2009). Over the last thirty years, quinoa seed has become an extremely popular food product, especially in Europe and North America (Jellen et al., 2015), because of its exceptional nutritional value (Repo-Carrasco et al., 2003). Quinoa grain is gluten-free and therefore can be eaten by people who have celiac disease (Pulvento $e t$ al., 2010). It has a high protein content (14-20\%) containing essential amino acids such as lysine, methionine and threonine which are limiting in cereals (Bhargava et al., 2007). Moreover, quinoa is rich in vitamins C, E and B complex, minerals, isoflavones and lipids (Koziol, 1992). The saponins, constituted up to $6 \%$ of seed coat, can be exploited for industrial and biomedical purposes (VegaGálvez et al., 2010). The aerial biomass of quinoa has been used as green fodder for animals such as cattle, pigs and poultry (Bhargava et al., 2006). Therefore, this species is considered as a multi-purpose agricultural crop with potential uses for both human and animal consumption and nutrition. The Food and Agriculture Organization of the United Nations (FAO) has declared the year 2013 as the international year of quinoa (FAO, 2012).

Data obtained from several studies conducted in areas of Mediterranean basin demonstrate the beneficial effects of organic farming in quinoa crop (table 1). Bilalis et al. (2012) conducted a two-year experiment in western Greece to investigate the influence of soil tillage [conventional tillage (CT) and minimum tillage (MT)] and organic fertilization [fertilization treatments: control, cow manure $(2000 \mathrm{~kg} \mathrm{ha}$ $\left.{ }^{1}\right)$ and seaweed compost $\left.\left(250 \mathrm{~kg} \mathrm{ha}^{-1}\right)\right]$ on growth, yield and quality of quinoa and found that the highest saponin yield (7.70-12.05 $\mathrm{kg} \mathrm{ha}^{-1}$ ) was observed in soils subjected to minimum soil tillage. Also, there were significant differences between the fertilization treatments with the highest values of seed yield (2485-2643 kg ha-1) and saponin content (0.42-0.45\%) observed in manure and compost treatments. Papastylianou et al. (2014) studied the response of quinoa and amaranth to different fertilization regimes [(control, inorganic fertilization (fertilizer 26-0-0 with $100 \mathrm{~kg} \mathrm{~N} \mathrm{ha}^{-1}$ ), compost (2000 kg ha-1) and cow manure $\left(2000 \mathrm{~kg} \mathrm{ha}^{-1}\right)$ ] and found that fertilization with compost showed higher values in yield $\left(8430 \mathrm{~kg} \mathrm{ha}^{-1}\right)$ and quality traits (18.8\% total 
ash, $2.87 \%$ crude fat and $14.7 \%$ crude protein) of quinoa biomass. They suggested that quinoa could be used as an alternative feed crop for substitution of spring legume species in Mediterranean semi-arid areas.

\section{Chia}

Chia (Salvia hispanica L.) is an annual plant of the Lamiaceae family and originated from southern Mexico and northern Guatemala (Ayerza and Coates, 2005). In preColumbian period, chia seeds were one of the four main components in the diet of Mesoamerican civilizations (Bochicchio et al., 2015). Currently, it has been rediscovered (Ayerza and Coates, 2009) and received remarkable attention due to its exceptional nutritional value (Borneo et al., 2010; Ixtaina et al., 2011). Seeds are great sources of polyunsaturated fatty acids, antioxidants, vitamins and minerals (Ayerza and Coates, 2009). The oil content of chia seeds ranges from 25 to $40 \%$, consisting $60 \%$ $\omega-3$ alpha-linolenic acid and 20\% $\omega-6$ linoleic acid (Mohd Ali et al., 2012). Both of these essential fatty acids are required by the human body for its health and they cannot be artificially synthesized (Pizarro et al., 2013). Several studies reported that chia consists one of the richest natural sources of $\omega-3$ fats and hence chia seeds were successfully used to increase the $\omega-3$ fatty acid content of animal products such as eggs, poultry and pork meat (Ayerza, 2011). In Europe, the use of chia for human consumption has been approved by the European Parliament and the European Council according to the directive 2009/827/EC (European Commission, 2009).

Bilalis et al. (2016) established a field experiment to determine the effect of plant densities (row spacing: 60 and $40 \mathrm{~cm}$ ) and organic fertilization [fertilization treatments: control, organic fertilizer (fertilizer 6-8-10 at a rate of 1000 $\left.\mathrm{kg} \mathrm{ha}^{-1}\right)$ and sheep manure $\left.\left(1800 \mathrm{~kg} \mathrm{ha}^{-1}\right)\right]$ on growth and fodder quality of quinoa crop under Mediterranean conditions. According to the results, there was a positive effect of increasing row spacing on biomass production (5587 and $14190 \mathrm{~kg} \mathrm{ha}^{-1}$ for 40 and $60 \mathrm{~cm}$, respectively). Fodder quality parameters were actually affected by organic fertilization. The highest crude protein (13.25\%) and acid detergent fiber $(\mathrm{ADF})$ content $(42.45 \%)$ were observed in organic fertilizer treatment, while, the highest neutral detergent fiber (NDF) (49.57\%) content was recorded under manure treatment. According to the authors, these high values can meet the requirements of lactating animals. Moreover, they emphasized that chia biomass is produced during the summer which is very important for the nutrition of ruminants since there is a lack of natural vegetation during this period.

\section{Nigella}

Nigella (Nigella sativa L.) is an annual medicinal plant of the Ranunculaceae family and is native to areas of southern Europe, North Africa, South and West Asia (Tuncturk et al., 2005). It is cultivated from the countries of the southern and eastern areas of the Mediterranean basin to Iran, Pakistan and India for seed yield and oil production (Gharby et al., 2015). Its seeds, the only part of the plant harvested and exploited, have been subjected to a series of pharmacological studies over the last three decades. The studies have shown that nigella seed oil and extracts have diuretic, antihypertensive, antidiabetic, anticancer, anthelmintic, analgesic, antimicrobial, anti-inflammatory, spasmolytic, hepatoprotective, gastroprotective, nephronprotective, antihypertensive and antioxidant effects (Riaz et al., 1996; Ahmad et al., 2013). The seeds are rich in unsaturated essential fatty acids, among which linoleic, oleic and palmitic acids are the most abundant (Kizil et al., 2008). In addition, the nigella seeds are also a source of minerals, including $\mathrm{Fe}, \mathrm{Na}, \mathrm{Cu}, \mathrm{Zn}, \mathrm{P}, \mathrm{Ca}$ and vitamins such as ascorbic acid, thiamin, niacin, pyridoxine, and folic acid (Takruri and Dameh, 1998). Nigella seeds contain 30-35\% oil and $0.5-1.5 \%$ essential oil which have several uses for pharmaceutical and food industries (Üstun et al., 1990; Ashraf et al., 2006). Thymoquinone is the major active compound in the crude extract of nigella oil and is characterized for antioxidant and anti-inflammatory effects in models of in vitro and in vivo studies as well as asthma, diabetes, encephalomyelitis, neurodegeneration, and carcinogenesis (Woo et al., 2012).

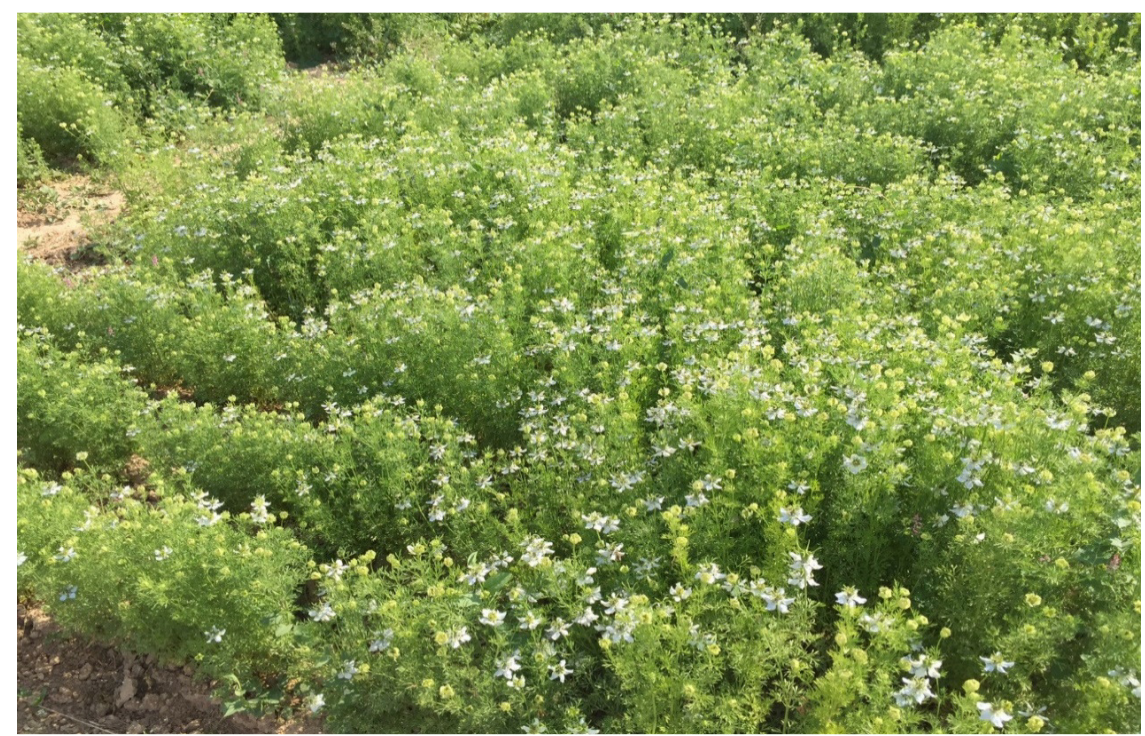

Fig. 1. Established nigella crop at flowering stage (June, 2016) in the organic experimental field of the Agricultural University of Athens (Roussis et al., 2017) 
During the spring and summer of year 2016, Roussis et al. (2017) set up an experiment at Agricultural University of Athens to investigate the effects of different seed rates (50 and $60 \mathrm{~kg} \mathrm{ha}^{-1}$ ) and fertilization [fertilization regimes: control, compost $(2000 \mathrm{~kg} / \mathrm{ha})$, sheep manure (2750 $\mathrm{kg} / \mathrm{ha})$, inorganic fertilizer $(15-15-15+5 \mathrm{~S}, 400 \mathrm{~kg} / \mathrm{ha})]$ on growth, yield and yield components of nigella crop (Fig. 1). They found that the different seed rates significantly affected the plant height with the highest values (18.2-22.7 $\mathrm{cm}$ ) recorded with $60 \mathrm{~kg} \mathrm{ha}^{-1}$. Moreover, they observed that seed yield and biological yield were significantly affected, maximum parameters $\left(911-1066 \mathrm{~kg} \mathrm{ha}^{-1}\right.$ and $3864-4063 \mathrm{~kg}$ $\mathrm{ha}^{-1}$ for seed yield and biological yield, respectively) were recorded with inorganic fertilization followed by compost (828-881 kg ha ${ }^{-1}$ and 3239-3455 kg ha ${ }^{-1}$ for seed yield and biological yield, respectively). They eventually demonstrated that there is a clear need for further studies on performance of nigella under Mediterranean conditions.

\section{Teff}

Teff (Eragrostis tef (Zucc.) Trotter), a member of the Poaceae family, originated in Ethiopia around 4000-1000 $\mathrm{BC}$ and is mainly grown for its grain mainly used in human consumption (Stallknecht et al., 1993; Tesfahunegn, 2014). It is a warm season $\mathrm{C}_{4}$ annual plant (Bedane et al., 2015) and is intermediate between tropical and temperate grass (Stallknecht et al., 1993). Teff has the potential to be one of those crops with beneficial health effects as it contains very low gluten, making it an extremely important component for the diet of people with either gluten intolerance or celiac disease (Roseberg et al., 2006). Teff makes excellent quality straw and has various uses mainly as fodder for cattle, and secondarily as bedding material, mulch and domestic fuel source (Assefa et al., 2001). In addition, teff is also gaining the interest of the people of Western world and serious efforts are being made to expand its cultivation in Europe and America (Belay et al., 2009).
Chroni (2016) established a field experiment in Greece during the summer of 2015 to investigate the effect of different plant densities (row spacing treatments: 20, 40 and $60 \mathrm{~cm}$ ) and fertilization (control, organic fertilizer (Bokashi) at a rate of $4200 \mathrm{~kg} \mathrm{ha}^{-1}$ and inorganic fertilizer (34.5-0-0) at a rate of $60 \mathrm{~kg} \mathrm{~N} \mathrm{ha}^{-1}$ ) on agronomic characteristics and yield of teff crop under Mediterranean conditions (Fig. 2). According to the results of this study, plant densities had no significant effect in teff measurements. On the contrary, fertilization had significant effect on number of grains per panicle but it did not affect the seed yield. The highest value (approx. 840 seeds per panicle) was recorded in organic fertilization treatment, followed by inorganic (approx. 590 seeds per panicle) and control (approx. 170 seeds per panicle). Furthermore, she reported that among fertilization treatments, dry weight per stem was actually affected. The highest dry weight per stem (approx. $5 \mathrm{~g}$ ) obtained in organic fertilization, while the lowest were found under inorganic fertilization (approx. 3.2. g) and control (approx. $2.6 \mathrm{~g}$ ). Finally, she demonstrated that organic fertilization had better impact on some agronomic characteristics, especially on plant biomass, and argued that further research is necessary to provide safe conclusions on the adaptability and performance of teff under Mediterranean conditions.

\section{Camelina}

Camelina (Camelina sativa (L.) Crantz) (Fig. 3), also known as false flax or gold of pleasure, is a cruciferous annual or summer oil seed plant originated from the Mediterranean and Central Asia (Zubr, 1997; Ionescu and Roman, 2009). It has been cultivated in Europe for centuries and is used as the most important oil crop from the Bronze and Iron Ages until the beginning of the Industrial Revolution (Ionescu and Roman, 2009). Recently, the interest in camelina has been renewed due to its very low requirements for tillage and weed control

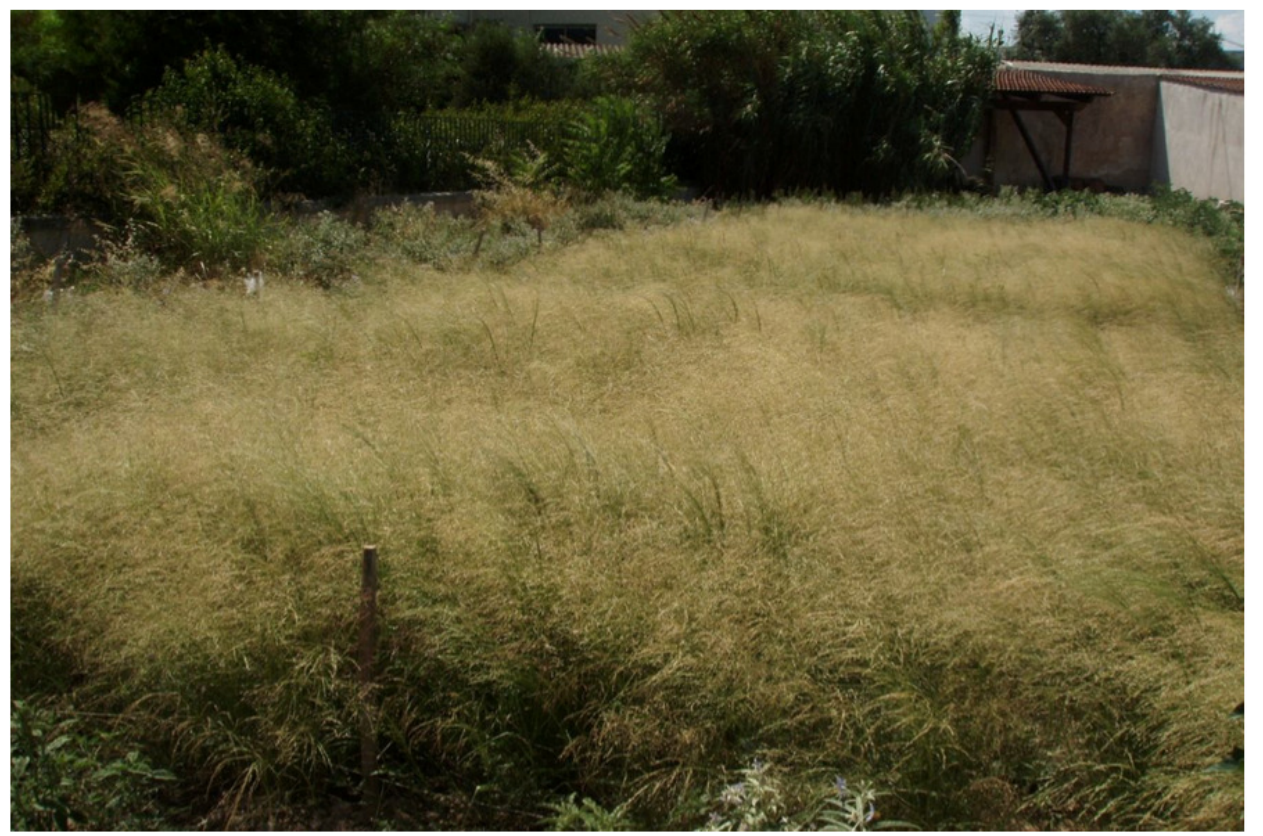

Fig. 2. Teff crop one month before harvest (July, 2015) in the experimental field of Agricultural University of Athens (Chroni, 2016) 


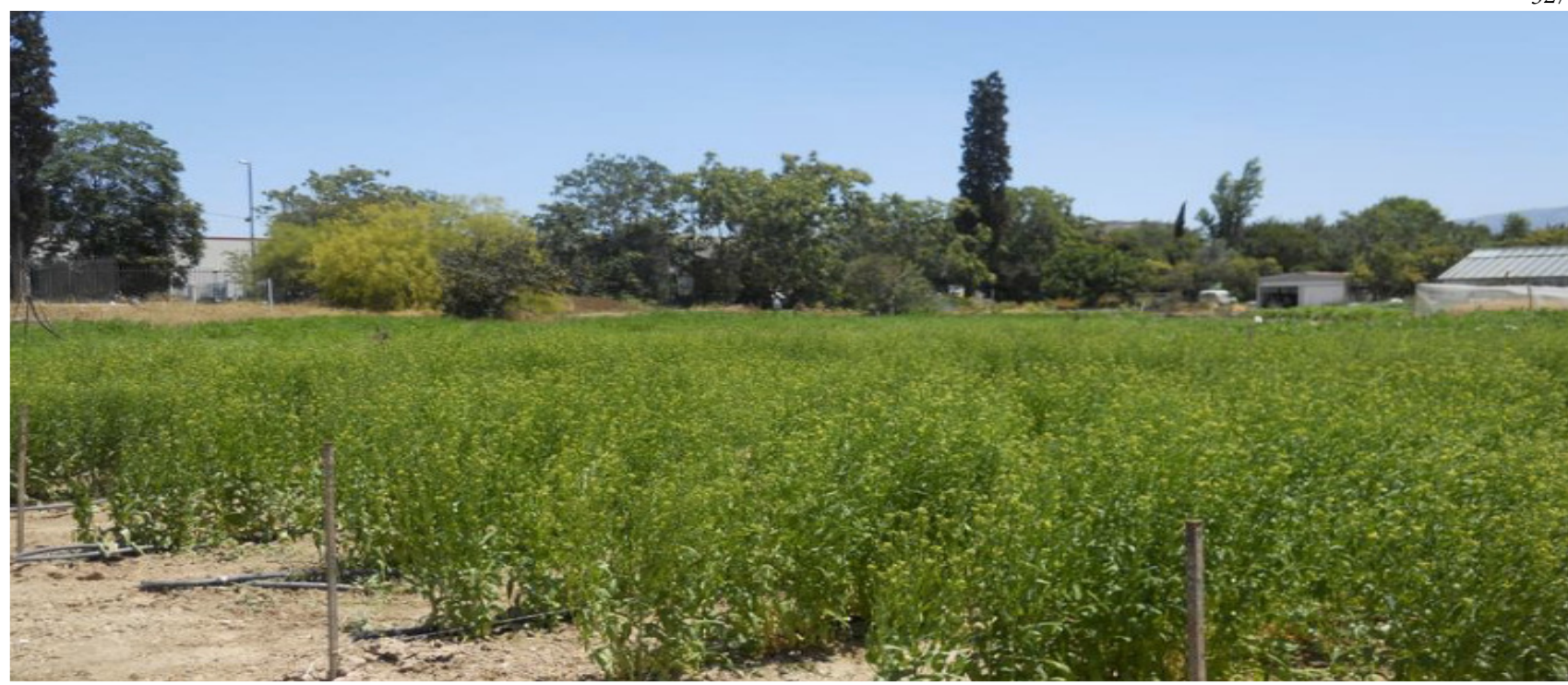

Fig. 3. Established camelina crop before passing into the maturity stage (June 2016) in Greece (Agricultural University of Athens) (Kobilakou, 2017)

(Budin et al., 1995; Abramovič and Abram, 2005). The crop is now being researched due to high $\alpha$-linolenic acid (38\%) content of its oil (Zubr, 1997). Alpha-linolenic acid is a nutritionally valuable omega-3 fatty acid which is generally found in significant quantities only in linseed and fish oils (Crowley and Fröhlich, 1998) and can reduce the incidence of cardiovascular disease as well as various health risks in humans (Ruxton et al., 2007). Camelina oil also is high in omega-6 fats (linoleic acid, approx. 15-20\%), vitamin E (approx. $110 \mathrm{mg} / 100 \mathrm{~g}$ ) and natural antioxidants such as tocopherols (Ionescu and Roman, 2009). Therefore, camelina offers an opportunity to supply the growing demand for high quality edible oils (Zurb, 1997).

In Greece, a field trial was conducted with the aim of investigating the effect of different fertilization regimes [control, inorganic fertilization (fertilizer 34.5-0-0 with 200 $\left.\mathrm{kg} \mathrm{N} \mathrm{ha}{ }^{-1}\right)$, compost $\left(8000 \mathrm{~kg} \mathrm{ha}^{-1}\right)$ and farmyard manure $\left(18000 \mathrm{~kg} \mathrm{ha}^{-1}\right)$ ] on growth and yield of camelina crop (Kobilakou, 2017). The results revealed that fertilization had a significant effect on yield and yield parameters such as thousand-seed weight. The maximum values (approx. 1820 $\mathrm{kg} \mathrm{ha}^{-1}$ and $1.35 \mathrm{~g}$ for seed yield and thousand-seed weight, respectively) were recorded with compost, followed by inorganic fertilization (approx. $1350 \mathrm{~kg} \mathrm{ha}^{-1}$ and $0.81 \mathrm{~g}$ ), control (approx. $1150 \mathrm{~kg} \mathrm{ha}^{-1}$ and $0.80 \mathrm{~g}$ ) and farmyard manure (approx. $830 \mathrm{~kg} \mathrm{ha}^{-1}$ and $0.73 \mathrm{~g}$ ). In the conclusions of this study, she mentioned that compost increased the yield of camelina and suggested further studies on the performance of camelina under different types and rates of fertilizers.

\section{Flax}

Flax or linseed (Linum usitatissimum L.) is the only species of Linaceae family that has economic as agronomic values (Copur et al., 2006) and is one of the oldest cultivated crops that continues to be widely grown for oil, fiber and food (Berglund, 2002). It originates from Europe and Southern Asia (Casa et al., 1999). The fiber, obtained from stems, is used to make fine linen and paper. Flax seed is a rich source of oil (41\%), proteins $(20 \%)$ and total dietary fiber (28\%) and contains $7.7 \%$ moisture and 3.3\% ash (Morris, 2007). In the past, the main use of flax oil was as a raw material for varnish, paints, linoleum and oilcloth industry, inks, leather and soaps (Laza and Pop, 2012). Flax oil has become popular for its nutritional and pharmaceutical values (Zhang et al., 2011). Nowadays, it is used in human consumption, medical purposes and animal feed (Laza and Pop, 2012). Flax oil is commonly known as the richest source of omega-3 fatty acid, $\alpha$-linolenic acid, which is one of the essential fatty acids (Madhusudhan, 2009). Several studies have shown that flax oil has a positive impact on many diseases, such as hyperlipidemia, colon tumor, mammary cancer and atherosclerosis (Zhang et al., 2011).

In a 2-year field experiment in the experimental field of Agricultural university of Athens, Greece, the influence of different tillage systems [conventional tillage (CT), minimum tillage (MT), no-tillage] and organic fertilization (vetch as green manure, faba bean as green manure and compost at a rate of $2500 \mathrm{~kg} \mathrm{ha}^{-1}$ ) on growth and yield of flax were determined (Bilalis et al., 2010). It was observed that tillage system had significant effect on seed yield and oil yield. The highest values (1761 and $670 \mathrm{~kg} \mathrm{ha}^{-1}$ for seed yield and oil yield, respectively) were obtained under minimum tillage system. The fertilization and especially the vetch and faba bean green manure had a significant influence on the oil content of the flax. Oil content (39.34\%) was significantly higher in plots fertilized with faba bean green manure. Finally, the researchers of this study reported that conservation tillage systems could increase the oil yield of flax.

\section{Emmer Wheat}

Emmer (Triticum turgidum L. ssp. dicoccon (Schrank) Thell.) is a primitive hulled allotetraploid wheat species developed from its correspondent wild form [Triticum dicoccoides (Koern. ex Asch. et Graebn.) Schweinf.] (Pagnotta et al., 2009; Özbek et al., 2012). It originates from Middle East (Iran, Iraq, Jordan, Syria, Palestine) and during the last century, the introduction of high-yielding and free- 
328

threshing wheats led to the decline of emmer cultivation in mountain regions and small areas of Mediterranean basin (Italy, Spain), Ethiopia, Iran, Transcaucasia, Central Europe, India and the Volga Basin (Marino et al., 2009; Pagnotta et al., 2009; Zaharieva et al., 2010). Nowadays, emmer accounts for $1 \%$ of the total world area cultivated with wheats. In ancient times, it was the main crop of Babylon, ancient Egypt and Greece (Zaharieva et al., 2010). Emmer is rich in protein (18-23\%), minerals and fiber (Marino et al., 2011). The findings of recent surveys demonstrated that emmer is a very healthy cereal, suitable for diets of people suffering from allergies, colitics, and high blood cholesterol (Marino et al., 2011). Moreover, it is characterized by the resistance to pest and disease, the tolerance to abiotic and biotic stress, the quality of seed protein and the high concentration of micronutrients such as $\mathrm{Zn}, \mathrm{Fe}$, and Mn (Marino et al., 2009; Zeharieva et al., 2010).

In Italy, a research study was carried out to evaluate the influence of olive pomace compost [fertilization treatments (each of them at a rate $80 \mathrm{~kg} \mathrm{~N} \mathrm{ha}^{-1}$ ): commercial organic mineral fertilizer (control), olive pomace compost A1 (OPC-A1) (composting mixture with $\mathrm{C} / \mathrm{N}$ ratio of 45 stopped at the end of active phase of bio-oxidation), olive pomace compost A2 (OPC-A2) (composting mixture with $\mathrm{C} / \mathrm{N}$ ratio of 45 processed until maturation), olive pomace compost $\mathrm{B} 1$ (OPC-B1) (composting mixture $\mathrm{C} / \mathrm{N}$ ratio of 30 stopped at the end of active phase) olive pomace compost B2 (OPC-B2) (composting mixture with $\mathrm{C} / \mathrm{N}$ ratio of 30 processed until maturation)] on growth, yield and quality of emmer wheat (Diacono et al., 2012). They observed that different fertilization treatments had no significant effect on growth and yield of emmer, however, they found that olive pomace compost showed an increase of $9.8 \%$ in grain yield compared to commercial mineral fertilizer treatment. The emmer grain protein was significantly affected by fertilization with the highest values obtained in the commercial mineral fertilizer (12.30\%) and matured compost with low $\mathrm{C} / \mathrm{N}$ ratio $(12.25 \%)$ treatments. Finally, they demonstrated that more experiments and data are needed to evaluate the possible long-term effects of olive pomace compost in the emmer crop.

\section{Conclusions}

Several studies, conducted under Mediterranean semiarid conditions and organic cropping system, have proved that innovative crops can also be grown for alternative uses. Quinoa and chia could be successfully used in animal feed. Moreover, quinoa could be exploited as a medicinal plant due to saponins extracted from seed coats. Nigella and camelina seeds contain oils which can have several uses in pharmaceutical and food industries. Flax seed oil is rich in omega- 3 fatty acids and can be accepted in the diets designed for specific health benefits. Emmer wheat has the potential for developing new health food products. According to the literature, it has been observed that innovative crops cultivated under organic system present better quality and similar yields as with those cultivated under conventional system, and in some cases, even higher. Taking all these into account, organic agriculture could also be characterized as innovative and not only as traditional.
Table 1. Innovative crops cultivated under Mediterranean conditions and their uses

\begin{tabular}{|c|c|c|c|}
\hline Crop Species & $\begin{array}{l}\text { Growing } \\
\text { Country }\end{array}$ & Uses of Crop & Citations \\
\hline \multirow{6}{*}{ Quinoa } & \multirow{4}{*}{ Greece } & Seed & Bilalis et al., 2012 \\
\hline & & Saponin & Bilalis et al., 2012 \\
\hline & & \multirow{2}{*}{ Fodder } & $\begin{array}{l}\text { Kakabouki } \\
\text { et al., } 2014\end{array}$ \\
\hline & & & $\begin{array}{l}\text { Papastylianou } \\
\text { et al., } 2014\end{array}$ \\
\hline & Italy & Seed & Pulvento et al., 2010 \\
\hline & Turkey & Seed & Geren, 2015 \\
\hline \multirow[b]{2}{*}{ Chia } & Greece & Fodder & Bilalis et al., 2016 \\
\hline & Italy & Seed & $\begin{array}{l}\text { Bochicchio } \\
\text { et al., } 2015\end{array}$ \\
\hline \multirow{2}{*}{ Nigella } & Greece & Seed & Roussis et al., 2017 \\
\hline & Turkey & Oil & Kizil et al., 2008 \\
\hline \multirow{2}{*}{ Teff } & \multirow{2}{*}{ Greece } & Seed & Chroni, 2016 \\
\hline & & Fodder & Chroni, 2016 \\
\hline \multirow{2}{*}{ Camelina } & Greece & Oil & Kobilakou, 2017 \\
\hline & Italy & Oil & Masella et al., 2012 \\
\hline \multirow[b]{2}{*}{ Flax } & Greece & Oil & Bilalis et al., 2010 \\
\hline & Italy & Fibre & $\begin{array}{l}\text { Rossini and } \\
\text { Casa, } 2003\end{array}$ \\
\hline $\begin{array}{l}\text { Emmer } \\
\text { Wheat }\end{array}$ & Italy & Seed & Diacono et al., 2012 \\
\hline
\end{tabular}

\section{References}

Abramovič H, Abram V (2005). Physico-chemical properties, composition and oxidative stability of Camelina sativa oil. Food Technology and Biotechnology 43(1):63-70.

Ahmad A, Husain A, Mujeeb M, Khan SA, Najmi AK, Siddique NA, ... Anwar F (2013). A review on therapeutic potential of Nigella sativa: A miracle herb. Asian Pacific Journal of Tropical Biomedicine 3:337-352.

Ashraf M, Ali Q, Iqbal Z (2006). Effect of nitrogen application rate on the content and composition of oil, essential oil and minerals in black cumin (Nigella sativa L.) seeds. Journal of the Science of Food and Agriculture 86:871-876.

Assefa K, Tefera H, Merker A, Kefyalew T, Hundera F (2001). Variability, heritability and genetic advance in pheno-morphic and agronomic traits of tef [Eragrostis tef (Zucc.) Trotter] germplasm from eight regions of Ethiopia. Hereditas 134:103-113.

Ayerza R (2011). Protein content, oil content and fatty acid profiles as potential criteria to determine the origin of commercially grown chia (Salvia hispanica L.).Industrial Crops and Products 34:1366-1371.

Ayerza R, Coates W (2005). Ground chia seed and chia oil effects on plasma lipids and fatty acids in the rat. Nutrition Research 25:995-1003.

Ayerza R, Coates W (2009). Influence of environment on growing period and yield, protein, oil and linolenic content three chia (Salvia hispanica L.) selections. Industrial Crops and Products 30:321-324.

Bedane GM, Saukuru AM, George DL, Gupta ML (2015). Evaluation of teff [Eragrostis tef (Zucc.) Trotter] lines for agronomic traits in Australia. Australian Journal ofCrop Science 9(3):242-247. 
Belay G,Zemede A, Assefa K, Metaferia G, Tefera H (2009). Seed size effect on grain weight and agronomic performance of tef [Eragrostistef (Zucc.) Trotter]. African Journal of Agricultural Research 4(9):836-839.

Berglund DR (2002). Flax: New uses and demands. In Janick J, Whipkey A (Eds). Trends in new crops and new uses. Alexandria VA ASHS Press pp 358-360.

Bhargava A, Shukla S, Ohri D (2006). Chenopodium quinoa - An Indian perspective. Industrial Crops and Products 23:73-87.

Bhargava A, Shukla S, Ohri D (2007). Genetic variability and interrelationship among various morphological and quality traits in quinoa (Chenopodium quinoa Willd.). Field Crops Research 101:104 116.

Bilalis DJ, Karkanis A, Papastylianou P, Patsiali S, Athanasopoulou M, Barla G, Kakabouki I (2010). Response of organic linseed (Linum usitatissimum L.) to the combination of tillage systems, (minimum, conventional and no-tillage) and fertilization practices: Seed and oil yield production. Australian Journal ofCropScience 4(9):700-705.

Bilalis D, Kakabouki I, Karkanis A, Travlos I, Triantafyllidis V, Hela D (2012). Seed and saponin production of organic quinoa (Chenopodium quinoa Willd.) for different tillage and fertilization. Notulae Botanicae Horti Agrobotanici Cluj-Napoca 40(1):42-46.

Bilalis D, Tabaxi I,Zervas G, Tsiplakou E, Travlos IS, Kakabouki I, Tsioros S (2016). Chia (Salvia hispanica) fodder yield and quality as affected by sowing rates and organic fertilization. Communications in Soil Science and Plant Analysis 47(15):17641770.

Bochicchio R, Rossi R, Labella R, Bitella G, Perniola M, Amato M (2015). Effects of sowing density and nitrogen top-dress fertilisation on growth and yield of chia (Salvia hispanica L.) in a Mediterranean environment: First results. Italian Journal of Agronomy 10(3):163-166.

Borneo R, Aguirre A, León AE (2010). Chia (Salvia hispanica L) gel can be used as egg or oil replacer in cake formulations. Journal of the Academy of Nutrition and Dietetics 110:946-94.

Budin JT, Breene WM, Putman DH (1995). Some compositional properties of camelina (Camelina sativa L. Crantz) seeds and oils. Journal of the American Oil Chemists' Society 72:309-315.

Carrubba A, Scalenghe R (2012). The scent of Mare Nostrum: medicinal and aromatic plants in Mediterranean soils. Journal of the Science of Food and Agriculture 92:1150-1170.

Casa R, Russell G, Lo Cascio B, Rossini F (1999). Environmental effects on linseed (Linum usitatissimum L.) yield and growth of flax at different stand densities. European Journal of Agronomy 11:267-278.

Ceccarelli S, Grando S, Baum M (2007). Participatory plant breeding in water-limited environments. Experimental Agriculture 43:411-435.

Chroni M (2016). Effects of sowing density on agronomic characteristics and yield of organic tef (Eragrostis tef). Msc Dissertation, Agricultural University of Athens (in Greek).

Copur O, Gur M, Karakus M, Demirel U (2006). Determination of correlation and path analysis amongyield components and seed yield in oil flax varieties (Linum usitatissimum L.). Journal of Biological Sciences 6:738-743.

CrowleyJG, Fröhlich A (1998). Factors affecting the composition and use of camelina. A Teagasc publication. Crops Research Centre, Oak Park, Carlow, Ireland.
Diacono M, Ferri D, Ciaccia C, Tittarelli F, Ceglie F, Verrastro V, ... Montemurro F (2012). Bioassays and application of olive pomace compost on emmer: effects on yield and soil properties in organic farming. Acta Agriculturae Scandinavica, Section B - Soil \& Plant Science 62(6):510-518.

European Commission (2009). 2009/827/EC: Commission Decision of 13 October 2009 authorizing the placing on the market of Chia seed (Salvia hispanica) as novel food ingredient under Regulation (EC) No 258/97 of the Europe Parliament and of the Council (notified under document C (2009) 7645). In: Official Journal L 294, 11/11/2009, pp $14-15$.

FAO (2012). Food and Agriculture Organization of the United Nations Statistics. Retrieved 2017 May 7 from http://faostat.fao.org.

Garcia MI, Raes D, Jacobsen S-E (2003). Evapotranspiration analysis and irrigation requirements of quinoa (Chenopodium quinoa) in the Bolivian highlands. Agricultural Water Management 60:119-134.

Georgakopoulos P, Travlos IS, Kakabouki I, Kontopoulou C-K, Pantelia A, Bilalis DJ (2016). Climate change and chances for the cultivation of new crops. Notulae Botanicae Horti Agrobotanici Cluj-Napoca 44(2):347353.

Geren H (2015). Effects of different nitrogen levels on the grain yield and some yield components of quinoa (Chenopodium quinoa Willd.) under Mediterranean climatic conditions. Turkish Journal of Field Crops 20:59-64.

Gharby S, Harhar H, Guillaume D, Roudani A, Boulbaroud S, Ibrahimi M, ... CharroufZ (2015). Chemical investigation of Nigella sativa L., seed oil produced in Morocco. Journal of the Saudi Society of Agricultural Sciences 14:172-177.

Giannakopoulos C, Kostopoulou E, Varotsos KV (2011). An integrated assessment of climate change impacts for Greece in the near future. Regional Environmental Change 11:1-15.

El-Hage Scialabba N, Müller-Lindenlauf M (2010). Organic agriculture and climate change. Renewable Agriculture and Food Systems 25(2):158169.

Ionescu (Truta) A, Roman GV (2009). Research on morphological and biological peculiarities of Camelina sativa (L.) Crantz species under the conditions of the central part of Romanian plain. Scientific Papers USAMV Bucharest, Series A, Vol LII:344348.

IPCC (2007). Intergovernmental Panel on Climate Change - Synthesis report. In: Metz ORD, Bosch PR, Dave R, Meyer LA (Eds). Fourth Assessment Report: Climate Change 2007. Cambridge University Press, Cambridge, UK,

Ixtaina VY, Mattea F, Cardarelli DA, Mattea MA, Nolasco SM, Tomas MC (2011). Supercritical carbon dioxide extraction and characterization of Argentinean chia seed oil. Journal of the American Oil Chemists' Society 88(2):289-298.

Jacobsen S-E (2003). The worldwide potential for quinoa (Chenopodium quinoa Willd.). Food Reviews International 19:167-177.

Jancurová M, MinarovičováL, Dandár A (2009). Quinoa - a review. Czech Journal of Food Science 27:71-79.

Jellen EN, Maughan PJ, Fuentes F, Kolano BA (2015). Botany, Phylogeny and Evolution. Chapter 1.1. In: FAO \& CIRAD. State of the Art Report of Quinoa in the World in 2013, Rome pp 12-23. 
330

Kakabouki I, Bilalis D, Karkanis A, Zervas G, Tsiplakou E, Hela D (2014). Effects of fertilization and tillage system on growth and crude protein content of quinoa (Chenopodium quinoa Willd.): An alternative forage crop. Emirates Journal of Food and Agriculture 26(1):18-24.

Khanal RC (2009). Climate Change and Organic Agriculture. The Journal of Agriculture and Environment 10:100-110.

Kizil S, Kirici S, Cakmak O, Khawar KM (2008). Effects of sowing periods and $\mathrm{P}$ application rates on yield and oil composition of black cumin (Nigella sativa L.). Journal of Food, Agriculture and Environment 6(2):242-246.

Kobilakou M (2017). Effects of organic fertilization on growth and agronomic characteristics of camelina (Camelina sativa). Msc Dissertation, Agricultural University of Athens (in Greek).

Kotschi J, Müller-Sämann K (2004). The Role of Organic Agriculture in Mitigating Climate Change-a ScopingStudy.IFOAM, Bonn.

Koziol M (1992). Chemical composition and nutritional evaluation of quinoa (Chenopodium quinoa Willd). Journal of Food Composition and Analysis 5:35-68.

Laza A, Pop G (2012). The influence of fertilization and seeding density on flax oil production quality. Research Journal of Agricultural Sciences $44(4): 96-102$

Madhusudhan B (2009). Potential benefits of flaxseed in health and diseaseA perspective. Agriculturae Conspectus Scientificus 74:67-72.

Maracchi G, Sirotenko O, Bindi M (2005). Impacts of present and future climate variability on agriculture and forestry in the temperate regions. Climatic Change 70(1-2):117-115.

Marino S, Tognetti R, Alvino A (2009). Crop yield and grain quality of emmer populations grown in central Italy, as affected by nitrogen fertilization. European Journal of Agronomy 31:233-240.

Marino S, Tognetti R, Alvino A (2011). Effects of varying nitrogen fertilization on crop yield and grain quality of emmer grown in a typical Mediterranean environment in central Italy. European Journal of Agronomy 34:172-180.

Masella P, Mapelli S, Pecchia P, Reggiani R, Russo R, Galasso I (2012). Camelina sativa L. a non-food energy crop: Agronomic and environmental performances in Lombardia, Italy. In: 20th Biomass Conference \& Exhibition, Milan, Italy pp 503-506.

Mohd Ali N, Yeap SK, Ho WY, Beh BK, Tan SW, Tan SG (2012). The promisingfuture ofChia,Salvia hispanica L.Journal of Biomedicine and Biotechnology ID: 171956.

Morris DH (2007). Flax - a health and nutrition primer, 4th edition. Retrieved 2017 May 6 from http://www.flaxcouncil.ca.

Müller A (2009). Benefits of Organic Agriculture as a Climate Change adaptation and mitigation strategy in developing countries. Environment for Development - Discussion Paper Series pp 1-9. Archived athttp://orgprints.org/16506/.

Niggi U, Schmid H, Fliessbach A (2007). Organic Farming and Climate Change. Geneva: International Trade Center (UNCTAD/WTO) and Research Institute of Organic Agriculture(FiBL).

Niggdi U, Fliessbach A, Hepperly P, Scialabba N (2009). Low Greenhouse Gas Agriculture: Mitigation and Adaptation Potential of Sustainable Farming Systems. FAO, April 2009, Rev2-2009.

Özbek Ö. Taskin BG, San SK, Eser V, Arslan O (2012). High-molecular- weight glutenin subunit variation in Turkish emmer wheat [Triticum turgidum L. ssp. dicoccon (Schrank) Thell] landraces. Plant Systematics and Evolution 298(9):1795-1804.

Pagnotta MA, Mondini L, Codianni P, Fares C (2009). Agronomical, quality, and molecular characterization of twenty Italian emmer wheat (Triticum dicoccon) accessions. Genetic Resources and Crop Evolution 56:299-310.

Papastylianou P, Kakabouki I, Tsiplakou E, Travlos I, Bilalis D, Hela D, Chachalis D, Anogiatis G, Zervas G (2014). Effects of fertilization on yield and quality of biomass of quinoa (Chenopodium quinoa Willd.) and green amaranth (Amaranthus retroflexus L). Bulletin UASVM Horticulture 71(2):287-292

Pearsall DM (1992). The origins of plant cultivation in South America. In: Cowan CW, Watson PJ (Eds). The Origins of Agriculture. Smithsonian Institute Press, Washington DC pp 173-205.

Pizarro PL, Almeida EL, Sammán NC, Chang YK (2013). Evaluation of whole chia (Salvia hispanica $\mathrm{L}$ ) flour and hydrogenated vegetable fat in pound cake.LWT - Food Science and Technology 54(1):73-79.

Pulvento C, Riccardi M, Lavini A, d'Andria R, Iafelice G, Marconi E (2010). Field trial evaluation of two Chenopodium quinoa genotypes grown under rain-fed conditions in a typical Mediterranean environment in South Italy.Journal of Agronomy and Crop Science 196:407 411.

Ragab R, Prudhomme C (2002). Climate change and water resources management in arid and semi-arid regions: Prospective and challenges for the 21st century. Biosystems Engineering81:3-34

Repo-Carrasco R, Espinoza C, Jacobsen S-E (2003). Nutritional Value and Use of the Andean Crops Quinoa (Chenopodium quinoa) and Kañiwa (Chenopodium pallidicaule). Food Reviews International 19(1-2):179189.

Riaz M, Syed M, Chaudhary FM (1996). Chemistry of the medicinal plants of the genus Nigella. Hamdard Medicus39:40-45.

Roseberg RJ, Norberg S, Smith J, Charlton B, Rykbost K, Shock C (2006). Yield and Quality of Teff Forage as a Function of Varying Rates of Applied Irrigation and Nitrogen. In: Research in the Klamath Basin 2005 Annual Report. Oregon State University Agricultural Experiment Station Special Report 1069:119-136.

Rötter R, van de Geijn SC (1999). Climate change effects on plant growth, crop yield and livestock. Climate Change 43:651-681.

Rossini F, Casa R (2003). Influence of sowing and harvest time on fibre flax (Linum usitatissimum $\mathrm{L}$ ) in the Mediterranean environment. Journal of Agronomy and Crop Science 189:191-196.

Roussis I, Travlos I, Bilalis D, Kakabouki I (2017). Influence of seed rate and fertilization on yield and yield components of Nigella sativa L. under Mediterranean semi-arid conditions. AgroLife Scientific Journal 6(1):218-223.

Ruiz KB, Biondi S, Oses R, Acuña-Rodríguez IS, Antognoni F, MartinezMosqueira EA, ... Molina-Montenegro MA (2014). Quinoa biodiversity and sustainability for food security under climate change. A review. Agronomy for Sustainable Development 34:349-359.

Ruxton CHS, Reed SC, Simpson MJ, Millington KJ (2007). The health benefits of omega-3 polyunsaturated fatty acids: a review of the evidence. Journal of Human Nutrition and Dietetics 20:275-285. 
Stallknecht GF, Gilbertson KM, Eckhoff JL (1993). Teff: food crop for humans and animals. In: Janick J, Simon JE (Eds). New crops. Wiley, New Yorkpp 231-234.

Takruri HRH, Dameh MAF (1998). Study of the nutritional value of black cumin seeds (Nigella sativa). Journal of the Science of Food and Agriculture 76(3):404410.

Tesfahunegn GB (2014). Response of yield and yield components of tef [Eragrostis tef (Zucc). trotter] to tillage, nutrient, and weed management practices in Dura Area, Northern Ethiopia. Hindawi Publishing Corporation International Scholarly Research Notices ID 439718.

Tuncturk M, Ekin Z, Turkozu D (2005). Response of black cumin (Nigella sativa $\mathrm{L}$ ) to different seed rate growth, yield components and essential oil content. Journal of Agronomy 4(3):216-219.

Üstun G, Kent L, Cekin N, Civelekoglu H (1990). Investigation of the technological properties of Nigella sativa L. (black cumin) seed oil. Journal of the American Oil Chemists' Society 67(12):71-86.

Vega-Gálvez A, Miranda M, Vergara J, Uribe E, Puente L, Martinez EA (2010). Nutrition facts and functional potential of quinoa(Chenopodium quinoa Willd). An ancient Andean grain: a review.Journal of the Science of Food and Agriculture 90:2541-2547.
Woo CC, Kumar AP, Sethi G, Tan KHB (2012). Thymoquinone: potential cure for inflammatory disorders and cancer. Biochemical Pharmacology 83(4):443451.

World Bank (2008). Agriculture for development policy brief: Adaptation and mitigation of climate change in agriculture. World Development Report 2008. Retrieved 2017 May 7 from: http://siteresources.worldbank.org/INTWDR2008/Resources/Brief_ AdptMitClimateChng_web.pdf.

Zaharieva M, Ayana NG, Hakimi AA, Misra SC, Monneveux P (2010). Cultivated emmer wheat (Triticum dicoccon Schrank), an old crop with promising future: a review. Genetic Resources and Crop Evolution 57:937-962.

Zhang Z-S, Wang L-J, Li D, Li S-J, Özkan N (2011). Characteristics of flaxseed oil from two different flax plants. International Journal of Food Properties 14(6):1286-1296.

Zubr J (1997). Oil-seed crop: Camelina sativa. Industrial Crops and Products 6:113-119. 